\title{
Kajian Mutu Ikan Kayu Bubuk Yang Dikemas Plastik Dengan Nitrogen Dan Tanpa Nitrogen
}

\author{
Pinini Enembe*, Daisy M. Makapedua, Grace Sanger, Bertie E. Kaseger, \\ Silvana D. Harikedua, Lena J. Damongilala
}

Program Studi Teknologi Hasil Perikanan, Jurusan Pengolahan Hasil Perikanan, Fakultas Perikanan dan Ilmu Kelautan, Universitas Sam Ratulangi, Manado.

*Korespondensi: pininienembe@gmail.com

(Diterima 25-07-2020; Direvisi 05-08-2020; Dipublikasi 18-08-2020)

\begin{abstract}
Fish is one of the food items that are sought after so that fish is the favorite of the capture fisheries sector, including the Skipjack fish. Efforts are needed to inhibit the spoilage process by preserving and processing fish fuming is an amalgamation of the process of salting, drying, and fumigating to prevent the fish damage. Adebowale et al. (2008), fumigation has several advantages, namely providing preservation effect, affecting flavor. The purpose of this study was to find out and study the quality and shelf life of katsuo powder that were packed with nitrogen and without nitrogen. Katsuo powder was stored in ambient temperature for 0,7 and 14 days in order to evaluate the quality of product during storage. The method is carried out for organoleptic test, water content (AOAC, 2005) and Total Place Count (TPC). The result of organoleptic test for appearance, odor and texture was an average of 7 which comply the Indonesia national standart (SNI). The result of water content of katsuo powder that packed with nitrogen during the storage period for 0,7 and 14 days showed increasing of water content according to the storage period experienced an increase in water content at a shelf life of 0,7 and 14 days with the highest value with a value of $13.15 \%$, the product still complies the SNI standards. Based on the results of the TPC study of katsuo powder which is packed in plastic with nitrogen does not comply the SNI, whereas katsuo powder which is packed in plastic without nitrogen on day 0 is too little to count while on day 7 and 14 it does not comply the SNI.
\end{abstract}

Keywords: Katsuo powder, nitrogen, without nitrogen.

Ikan adalah salah satu bahan pangan yang banyak dicari orang sehingga ikan menjadi primadona sektor perikanan tangkap yang diantaranya adalah ikan Cakalang. Adanya upaya untuk menghambat proses pembusukan dengan cara pengawetan dan pengolahan. Pengasapan ikan merupakan penggabungan dari proses penggaraman, pengeringan dan pemberian asap untuk mencegah kerusakan ikan. Tujuan penelitian ini untuk mengetahui dan mempelajari mutu dan masa simpan ikan kayu bubuk yang dikemas dengan nitrogen dan tanpa nitrogen. Metode penelitian yang digunakan yaitu uji organoleptik, uji kadar air (AOAC, 2005) dan Angka Lempeng Total (ALT) dengan perlakuan penyimpanan 0 hari, 7 hari dan 14 hari. Berdasarkan hasil penelitian uji organoleptik kenampakan, bau dan tekstur dengan nilai rata-rata 7 memenuhi standar SNI. Berdasarkan hasil uji kadar air ikan kayu bubuk yang dikemas plastik dengan nitrogen dan tanpa nitrogen mengalami kenaikan kadar air pada masa simpan 0, 7 dan 14 hari dengan nilai tertinggi dengan nilai 13,15\%, produk masih memenuhi standar SNI. Berdasarkan hasil penelitian ALT ikan kayu bubuk yang dikemas plastik dengan nitrogen tidak memenuhi SNI, sedangkan ikan kayu bubuk yang dikemas plastik tanpa nitrogen pada hari ke 0 terlalu sedikit untuk dihitung sedangkan pada hari ke 7 dan 14 tidak memenuhi SNI.

Kata kunci: Ikan kayu, nitrogen, tanpa nitrogen.

\section{PENDAHULUAN}

Indonesia mempunyai potensi sumberdaya ikan yang cukup tinggi, baik dari segi jumlah maupun dari segi jenis. Ikan Cakalang (Katsuwonus pelamis L) merupakan salah satu produk unggulan di Sulawesi Utara. Kandungan protein dan air pada ikan cukup tinggi oleh karena itu ikan sangat mudah mengalami pembusukan. Proses pengawetan dengan cara pengolahan dilakukan untuk menghambat proses pembusukan. Adebowale et al. (2008), pengasapan memiliki beberapa keuntungan yaitu memberikan efek pengawetan, mempengaruhi citarasa, salah satu proses pengawetan dengan metode pengasapan ialah ikan kayu.

Pengolahan Ikan kayu merupakan gabungan dari dua proses yaitu proses pengasapan dan pengeringan. Ikan kayu merupakan salah satu produk unggulan di bidang perikanan Sulawesi Utara. Salah satu perusahaan ikan kayu ialah UD. Karya Mandiri Bersama kota Bitung. Ikan kayu memiliki struktur daging yang keras membuat produk ini awet (Zuraidah, 2014). Jenis ikan yang 
digunakan pada penelitian ini ialah ikan cakalang. Salah satu penyebab kemunduran mutu pada ikan kayu ialah karena pertumbuhan bakteri dan terjadinya oksidasi.

\section{MATERIAL DAN METODE}

\section{Alat dan Bahan}

Alat yang digunakan untuk uji organoleptik pulpen, lembar penilaian (score sheet) dan piring kecil. Alat-alat yang digunakan untuk analisa kadar air, yaitu cawan porselin, desikator, oven dan timbangan analitik. Alat untuk pengujian ALT ialah Auto claf, incubator, tabung huss, lampu spritus, erlenmeyer, pipet, mikroskop, cawan petri, kaca preperat, spatula, blender, pisau, baki, talenan, magnetic stirrer.

Bahan yang digunakan dalam penelitian ini ialah ikan kayu serut yang diproduksi oleh UD. Karya Mandiri Bersama Kota Bitung. Bahan yang digunakan untuk pengujian ALT yaitu media Nutrien Agar (NA) yang diproduksi oleh produksi oleh Merck KGaA (Merck Group), Akuades, $\mathrm{NaCl}$ yang diproduksi di PT Widatra Bhakti, silica gel, spritus.

Bahan baku yang digunakan ialah ikan cakalang diolah menjadi ikan kayu terlebih dahulu kemudian ikan kayu digiling halus hingga menjadi bubuk kemudian dikemas plastik dengan nitrogen dan tanpa nitrogen sebanyak $5 \mathrm{~kg}$ diproduksi oleh UD. Karya Mandiri Bersama kota Bitung kemudian dibawa ke laboratorium Penanganan dan Pengolahan Hasil Perikanan Fakultas Perikanan dan Ilmu Kelautan Universitas Sam Ratulangi Manado.

Sampel ikan kayu bubuk dikemas plastik dengan nitrogen dan tanpa nitrogen kemudian dilakukan pengujian organoleptik, kadar air dan ALT. Sampel diambil sebanyak $2 \mathrm{~kg}$ untuk pengujian organoleptik, $3 \mathrm{~g}$ untuk kadar air, dan sampel dihaluskan kemudian ditimbang sebanyak $25 \mathrm{~g}$ untuk pengujian ALT.

\section{Parameter Uji Organoleptik (SNI 01-2346-2006)}

Uji organoleptik merupakan pengujian yang menggunakan indra manusia. Uji organoleptik meliputi bau, tekstur dan penampakkan. Uji organoleptik hanya dilakukan pada penyimpanan hari ke 0 karena produk ikan kayu serut yang dikemas plastik dengan nitrogen dan tanpa nitrogen merupakan produk tambahan pangan dan merupakan produk kering yang akan lama mengalami perubahan aroma, tekstur dan kenampakan. Uji organoleptik yang dilakukan terhadap produk ikan kayu serut adalah Uji segi tiga atau triangle test dilakukan terhadap tingkat kesukaan oleh panelis dengan menggunakan skala angka 1 paling rendah dan angka 9 paling tinggi. Banyak panelis dalam uji organoleptik ikan kayu bubuk ialah sebanyak 31 orang mahasiswa Teknologi Hasil Perikanan.

\section{Kadar Air (AOAC, 2005)}

Kadar air ikan kayu ini dianalisa menggunakan metode gravimetrik. Sebanyak 5 gram ikan kayu digunakan sebagai sampel. Persentase kadar air dihitung sebelum dan sesudah pengeringan. Prinsip dari metode ini adalah berdasarkan penguapan air yang ada dalam bahan dengan jalan pemanasan, kemudian ditimbang sampai berat konstan. Pengurangan bobot yang terjadi merupakan kandungan air yang terdapat dalam bahan.

\section{Analisa Angka Lempeng Total (ALT) SNI. 2332.3:2015}

Metode Penentuan Angka Lempeng Total ini digunakan untuk menentukan jumlah total mikroorganisme aerob dan anaerob pada produk perikanan. Setelah masa inkubasi, koloni yang tumbuh pada cawan petri dihitung dengan jumlah koloni yang dapat diterima 25-250 koloni per cawan dengan menggunakan alat Colony Counter.

\section{Analisa Data}

Data yang diperoleh dari uji organoleptik adalah data kuantitatif. Data kuantitatif adalah data dalam bentuk grafik. Data untuk uji organoleptik, kadar air, dan ALT yang diperoleh, ditentukandengan mencari nilai rata-rata kemudian disajikan dalam bentuk grafik. 


\section{HASIL DAN PEMBAHASAN}

\section{Uji Organoleptik}

Profil hasil uji organoleptik ikan kayu bubuk yang dikemas plastik dengan nitrogen dan tanpa nitrogen tersaji pada Gambar 1. Gambar 1 memperlihatkan bahwa produk ikan kayu tanpa nitrogen memiliki bau dan kenampakan yang lebih disukai.

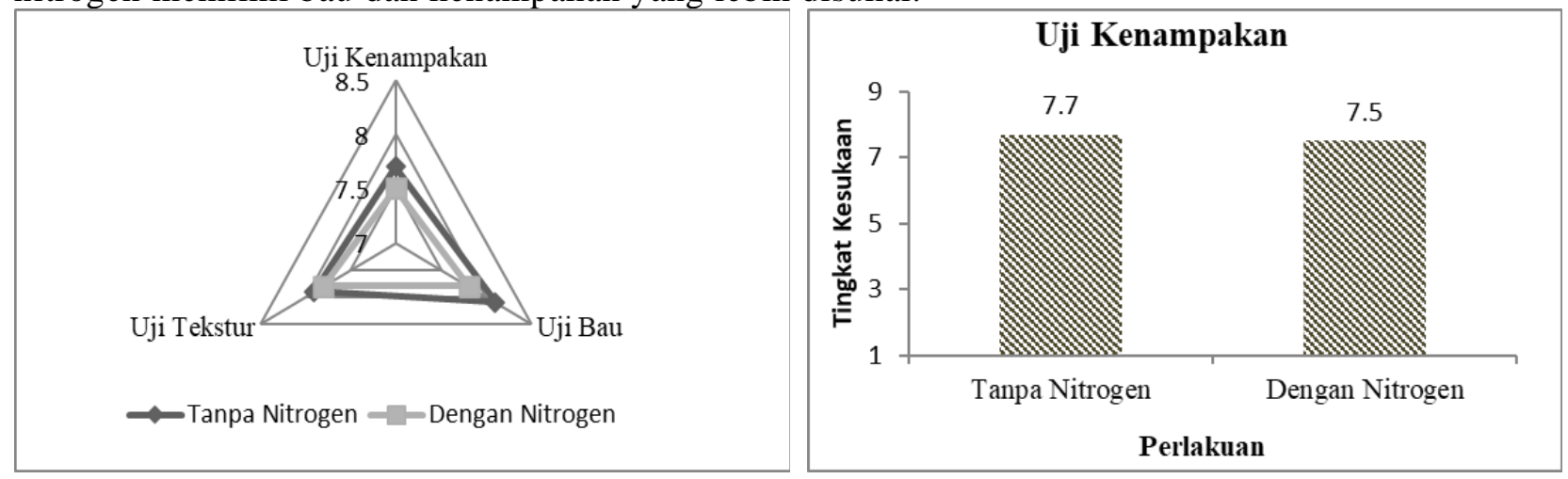

Gambar 1.Profil hasil uji organoleptik ikan kayu bubuk yang dikemas plastik dengan nitrogen dan tanpa nitrogen.
Gambar 2.Hasil penilaian panelis terhadap nilai organoleptik (kenampakan) ikan kayu bubuk yang dikemas plastik dengan nitrogen dan tanpa nitrogen.

\section{Uji Kenampakan}

Gambar 2 menunjukkan bahwa penilaian panelis untuk produk ikan kayu bubuk yang dikemas plastik dengan nitrogen dan tanpa nitrogen dengan kenampakan terbaik ada pada produk ikan kayu bubuk yang dikemas plastik tanpa nitrogen. Nilai rata-rata 7 dengan artian suka. Giullen dan Manzanos (2002) melaporkan bahwa asap dapat berperan sebagai pemberi warna pada tubuh ikan sehingga ikan yang diawetkan dengan proses pengasapan berwarna kuning keemasan dan dapat membangkitkan selera konsumen untuk menikmatinya. Semakin tinggi konsentrasi asap yang diberikan maka warna ikanpun akan semakin gelap atau kecoklatan.

\section{Aroma}

Nilai rata-rata organoleptik (aroma) ikan kayu bubuk yang dikemas dengan nitrogen dan tanpa nitrogen dapat dilihat pada Gambar 3. Berdasarkan hasil penelitian dapat dilihat tidak ada perbedaan aroma antara produk yang dikemas dengan nitrogen dan tanpa nitrogen (Gambar 3). Nilai rata-rata 7-8 dengan artian suka-sangat suka. Semakin tinggi konsentrasi asap yang diberikan maka aroma dan rasa asap pada ikan pun akan semakin meningkat dan ikan yang baru mengalami proses pengasapan memiliki aroma asap yang lembut sampai cukup tajam atau tajam, tidak tengik, tanpa bau busuk, tanpa bau asing, tanpa bau apek dan asam (Martinez et al., 2007).

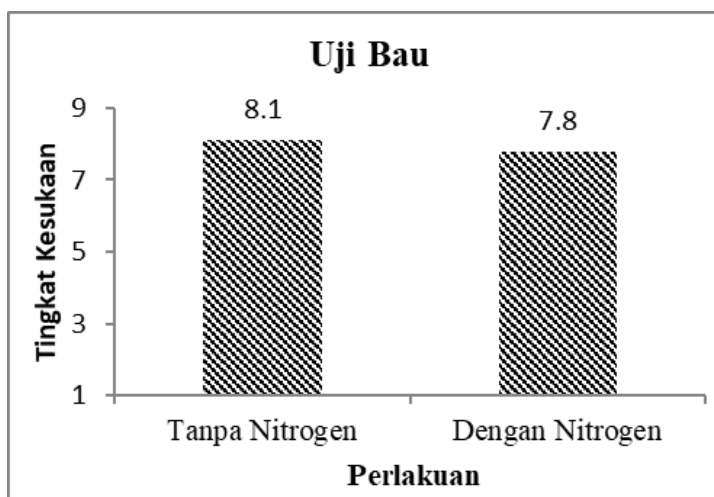

Gambar 3.Hasil penilaian panelis terhadap nilai organoleptik (aroma) ikan kayu bubuk yang dikemas plastik dengan nitrogen dan tanpa nitrogen.

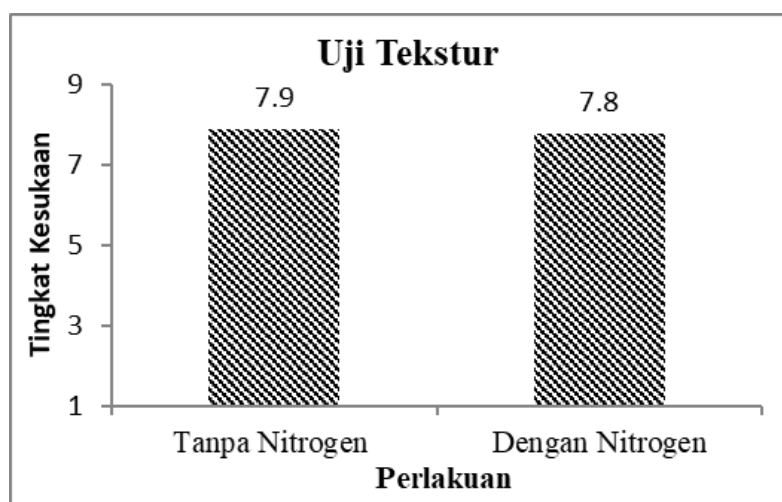

Gambar 4.Hasil penilaian panelis terhadap nilai organoleptik (tekstur) ikan kayu bubuk yang dikemas plastik dengan nitrogen dan tanpa nitrogen. 


\section{Tekstur}

Nilai rata-rata organoleptik (tekstur) ikan kayu bubuk yang dikemas plastik dengan nitrogen dan tanpa nitrogen tersedia pada Gambar 4. Hasil penelitian menunjukkan bahwa penggunaan nitrogen dan tanpa nitrogen pada ikan kayu bubuk tidak mengubah tekstur dari produk ikan kayu bubuk dengan nilai rata-rata 7 dengan artian suka. Menurut Nabila et al., (2017) lama pengasapan dan suhu yang digunakan dalam proses pengasapan, sehingga tekstur pada ikan asap terasa cukup kering atau kurang kering, padat dan kompak pada parameter tekstur.

\section{Kadar Air}

Nilai rata-rata kadar air ikan kayu bubuk yang dikemas plastik dengan nitrogen dan tanpa nitrogen dapat dilihat pada Gambar 5. Berdasarkan Gambar 5 dapat diketahui bahwa kadar air pada produk ikan kayu bubuk yang dikemas plastik dengan nitrogen mengalami kenaikan kadar air selama masa simpan 0,7 dan 14 hari pada suhu ruang, sedangkan produk ikan kayu bubuk yang dikemas plastik tanpa nitrogen mengalami penurunan kadar air pada masa simpan hari ke 7 dan mengalami kenaikan kadar air pada masa simpan hari ke 14. Menurut Kaparang, et al., (2013) naiknya kadar air disebabkan karena kelembaban ruangan penyimpanan lebih tinggi dari produk sehingga produk akan menyerap air yang mengakibatkan kadar air produk tinggi. Selanjutnya, kadar air maksimal yang dianjurkan berdasarkan standar mutu ikan kayu (SNI No.2691.1-2009) maksimal adalah 20\%. Secara umum kadar air seluruh produk ikan kayu yang yang diujikan sampai pada hari penyimpanan ke-14 masih memenuhi SNI yaitu $20 \%$.

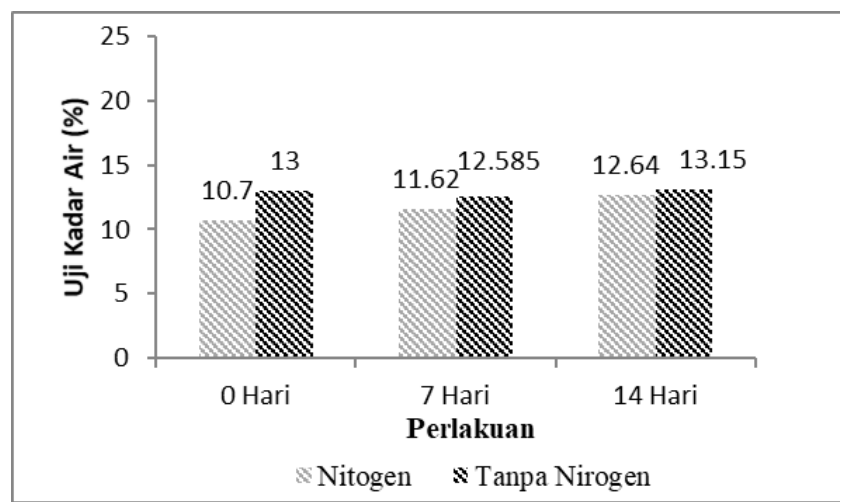

Gambar 5. Hasil pengujian kadar air pada produk ikan kayu bubuk yang dikemas plastik dengan nitrogen dan tanpa nitrogen penyimpanan pada suhu ruang.

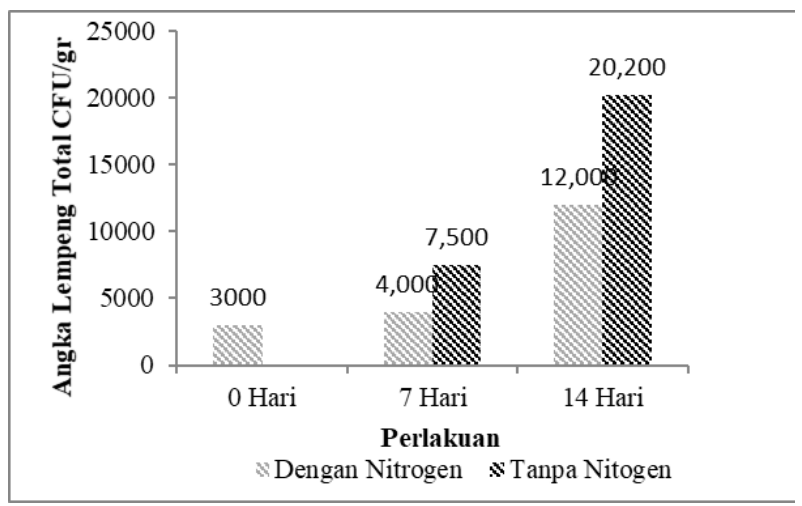

Gambar 6. Angka Lempeng Total ikan kayu bubuk yang dikemas plastik dengan nitrogen dan tanpa nitrogen pada penyimpanan suhu ruang.

\section{Angka Lempeng Total (ALT)}

Diperoleh nilai rata-rata angka lempeng total ikan kayu bubuk yang dikemas nitrogen dan tanpa nitrogen terdapat pada gambar 6.

Hasil ALT pada bubuk ikan kayu yang dikemas plastik dengan nitrogen pada hari ke 0 dengan jumlah koloni $3.000\left(3 \times 10^{3}\right) \mathrm{CFU} / \mathrm{g}$ pada perlakuan masa simpan hari ke 7 dengan total koloni $4.000\left(4 \times 10^{3}\right) \mathrm{CFU} / \mathrm{g}$ dan pada perlakuan masa simpan hari ke 14 dengan total koloni $12.000\left(1,2 \times 10^{3}\right) \mathrm{CFU} / \mathrm{g}$. Hasil penelitian pada sampel ikan kayu bubuk yang dikemas plastik tanpa nitrogen pada hari ke 0 dengan pertumbuhan bakteri 20 koloni berdasarkan standar SNI berdasarkan standar SNI ALT 2332.3:2015 jumlah koloni yang dapat dihitung sebanyak 25-250 koloni. Pada perlakuan masa simpan hari ke 7 dengan total koloni $7.500\left(7,5 \times 10^{3}\right)$ CFU/g dan pada perlakuan hari ke 14 dengan total koloni $20.200\left(2,0 \times 10^{3}\right)$ CFU/g koloni.

Pertumbuhan bakteri pada ikan juga sangat dipengaruhi oleh suhu, semakin rendah suhu maka ikan semakin lambat mengalami pertumbuhan bakteri. Mikroba biasanya berasal dari lingkungan sekitar yang kebanyakan merupakan mikroba pembusuk. Selain itu, mikroba dapat berasal dari hasil olahan suatu bahan pangan serta pada kondisi tertentu saat penyimpanan. Karena mikroba dapat kita jumpai di mana saja maka bahan pangan sangat jarang dijumpai dalam keadaan steril (Suter, 2000). Berdasarkan persyaratan total bakteri ALT yang dikeluarkan oleh Badan 
Standarisasi Nasional Indonesia (SNI) 2691.1:2009 bahwa jumlah bakteri ikan kayu yaitu maksimal $1,0 \times 10^{3} \mathrm{CFU} / \mathrm{g}$.

\section{KESIMPULAN}

Hasil uji organoleptik kenampakan, aroma dan tekstur pada ikan kayu bubuk yang dikemas plastik dengan nitrogen dan tanpa nitrogen, produk dapat diterima oleh panelis dan memenuhi standar yang sudah ditetapkan SNI. Hasil uji kadar air pada produk ikan kayu bubuk yang dikemas plastik dengan nitrogen dan tanpa nitrogen memenuhi SNI. Hasil uji Angka Lempeng Total pada produk ikan kayu bubuk yang dikemas nitrogen pada perlakuan masa simpan hari ke 0,7 dan 14 hari tidak memenuhi standar SNI. Produk ikan kayu bubuk yang dikemas plastik tanpa nitrogen pada perlakuan masa simpan 0 jumlah koloni bakteri terlalu sedikit untuk dihitung sedangkan pada perlakuan masa simpan hari ke 7 dan 14 tidak memenuhi standar SNI. Standar koloni yang

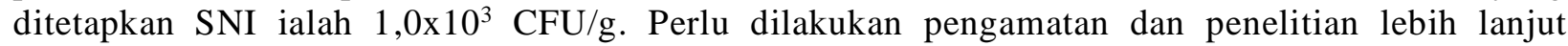
mengenai ikan kayu bubuk yang dikemas nitrogen dan tanpa nitrogen tentang pengujian kimia ikan kayu sesuai standar SNI.

\section{DAFTAR PUSTAKA}

Adebowale BA, D. L. Desember 2012 : 87-96. Comparative Quality Assesment Of Fish (Clarias Gariepinus) Smoked With Cocoa Pod Husk And Three Other Different Smoking Material. J Food Technol, Vol. 2, No. 2.

AOAC. 1995. Offiicial Methods Of Analysis Of The Association Of Official Analytical. Chemist .

Guillen, M. A. 2002. Study Of The Volatile Composition Of Anaqueous Oak Smoke Preparation. Food Chemistry \&9: 283292- .

Indonesia, B. S. 2015. Cara Uji Mikroba- Bagian 3 Penentuan Angka Lempeng Total (ALT) Pada Produk Perikanan. SNI. 2332.3:2015. ICS 67.050.

Indonesia, B. S. 2009. Ikan Kayu Bagian Spesifikasi . SNI 02-2691.1. ICS 67.120.30.

Kaparang. R., H. S. 2013. Penentuan Mutu Ikan Tandipang (Dussumieria acuta C.V) Asap Kering Selama Penyimpanan Suhu Kamar. Jurnal Media Teknologi Hasl Perikanan .

Martinez, O. S. 2007. Sensorial And Physicochemical Caharacteristics Of Salmon (Salmo salar) Treated By Different Smoking Process During Storage. Food Science And Technology Internasional , 877-484.

Nabila,. T. 2017. Karakteristisasi Organoleptik, Kimia, Dan Mikroba Ikan Kayu Cakalang ( Katsuwonus pelamis L) Dan Ikan Kayu Tongkol (Euthynnus affinis) yang Diproduksi di Kota Kendari. Jurnal Sains dan Teknologi Pangan , 530-541.

Soekarto, S. 1985. Penilaian Organoleptik untuk Industri Pangan dan Hasil Pertanian. Bharata Karya Aksara .

Suter, I. 2000. Kajian Aplikasi Teknologi Pangan dalam Upaya Menghasilkan Produk Bermutu. Yogyakarta: Universitas Gadjah Mada Press.

Zuraida, S. 2014. Tesis Strategi Pemasaran Produk Ikan Kayu (Arabushi) Di Kota Banda Aceh. Makassar: Universitas Hasanuddin. 